\title{
The Empirical Analysis of High-tech Trade Imbalance Between China and the US
}

\author{
Yiming Zhao \\ Department of History and Chinese language and literature, JILIN UNIVERSITY, 2699 Qianjin Street, Changchun City, Jilin Province
}

\begin{abstract}
The United States, as a leader in technology industry, has been in a deficit position for a long time in the high-tech trade between China and the United States, which has been increasing year by year. This is obviously contrary to traditional international trade theory and the comparative advantages of the two countries. Based on the US policy restrictions on China 's high-tech product exports, the enhancement of China 's independent innovation capabilities, and international direct investment in China, this article conducts an empirical analysis to explore the reasons for the China-US high-tech trade imbalance and then gives corresponding policy recommendations.
\end{abstract}

\section{Introduction}

The United States and China, as the first and second largest economies in the world, have close relation on trade. However, the trade between the two countries is in a state of imbalance for long time, especially in the hightech field. According to Chinese statistics, the United States began to have a trade deficit in 1993 in Sino-US trade with a number of 6.3 billion dollars, which rose to $\$ 58.6$ billion in 2003, 8 times larger than that of 1993 .

According to the US Bureau of Economic Analysis, China and the United States had an overall deficit of 283.6 billion US dollars in 2008 and 380.8 billion US dollars in 2018. The deficit increased more than 100 billion US dollars in the ten years. According to US Census Bureau statistics, the gap between China and the US in high-tech trade in 2006 reached 54.982 billion U.S. dollars, which increased to 115.691 billion U.S. dollars in 2016, more than doubling in ten years. This imbalance runs counter to the theory of comparative advantage and it is of great significance to explore the causes of this interesting phenomenon.

\section{Literature review}

Adam Smith is the first one who put forward the theory of absolute cost in his book Research on the Nature and Causes of National Wealth in 1776. In this book, he pointed that the reason for international trade is the difference in absolute costs between countries. Ricardo developed this theory and proposed the principle of comparative advantage in his book-Principles of Political Economy and Taxation in 1817. He believed that the international trade was based on relative differences in production technology rather than absolute differences.
Swedish economist Heckscher (1919) put aside the differences in production technology between the two countries in his article-The Impact of Foreign Trade on Income Distribution and studied the impact of resource endowment differences on international trade. Ohlin (1935) explained this theory further in his book International Trade. People combined the two sights and called it $\mathrm{H}-\mathrm{O}$ theory. The theory holds that a country tends to export products that use its abundant production factors intensively and imports products that use its scarce production factors intensively. However, Leontief (1953) analyzed the US import and export data in 1947 in the report Domestic Production and Foreign Trade: The American Capital Position Re-Examined and found that the capital-labor ratio of US exports was lower than the capital-labor of imported substitute ratio, which challenged the H-O theory. Vanek (1968) established the $\mathrm{H}-\mathrm{O}-\mathrm{V}$ model based on the H-O theory and proposed a linear function of the volume of international trade and the endowment of a country's factors. He believed that international trade was essentially the international exchange of factors rather than commodities. Later Leamer (1980) pointed out the problem of the mystery of Leontief in The Leontief Paradox, Reconsidered. He believed that the capital-labor ratio of net exports should be compared with the capital-labor ratio of domestic consumption; Trefler (1993) introduced technical differences and domestic preferences in his article International Factor Price Differences, Leontief was right! and improved the theory. Although theories above are expressed differently, they essentially believe that the reason for international trade is the difference in product prices.

Factor endowments have become diversified as the theory of comparative advantage developed. Nontraditional factors such as technology, human capital, 
population growth and regional systems have gradually been added. Balassa (1987) proposed the comparative advantage stage theory in Comparative Advantage. He believed that a country's factor endowment would change with the continuous development of the country's economy and the comparative advantage of imported and exported goods will change accordingly. Then, Oniki \& Uzawa (1965) proposed in the Patterns of Trade and Investment in a Dynamic Model of International Trade that the accumulation of endogenous capital and population growth would change the comparative advantage between countries, and then change their respective trade model. Grossman \& Helpman (1990) in Trade; Innovation; And Growth believed that the reason for the dynamic evolution of comparative advantage was the investment in research and development (R \& D) and technological advancement in a country. In addition to the diversification of endowments and endogenous and exogenous development, the areas of application of comparative advantages are also expanding, from the initial explanation of international trade to domestic economic development such as domestic regional trade and industrial structure upgrading.

Although the theory of comparative advantage is of great significance for the analysis of international trade, the current reasons for the imbalance of high-tech trade between China and the United States cannot be explained by this theory. Liu Wei (2009) proposed that the trade deficit in the communication products between China and the United States in the high-tech trade deficit is much larger than that in other high-tech products. Chen Peng and Xiong Pinsan (2013) further pointed out that the United States has transferred some of the manufacturing and processing links of high-tech product that have entered the recession to countries with lower labor costs, such as China, to reduce the expense. After the production of the product is completed, it is exported abroad. This transfer of high-tech industries has promoted the growth of foreign-invested enterprises' investment in China, including the United States, which has also promoted the export of high-tech products by domestic and foreignfunded enterprises. However, its substitution effect on China's imported high-tech products is limited, resulting in a growing trade deficit between China and the United States in high-tech products. Shen Guobing (2006) proposed that the United States imposed trade sanctions and technology embargoes on China after 1989, and strengthened the export control of high-tech products in China, resulting in distortion of China's imports of hightech products from the United States, leading to a hightech trade deficit between China and the United States. Du Li (2006) further proposed that the United States has always been "warning" to China and has always restricted the export of high-tech products related to safety issues, such as nuclear power plants, satellites, supercomputers, and CNC machine tools. This has led to the expansion of the Sino-US high-tech trade deficit. Chen Peng and Xiong Pinsan (2013) pointed out that since China's accession to the WTO, investment in independent innovation has been increasing, and the number of patents granted has also increased significantly. From 2001 to 2009, China's R \& $\mathrm{D}$ investment in high-tech industries increased by nearly
7.4 billion yuan, and the number of three patents granted increased by nearly 470,000.The increasing level of China's independent innovation has reduced China's imports of high-tech products, and to some extent has led to an increase in the trade deficit between China and the US in high-tech products. Kang Meiling (2006) pointed out that the inconsistent statistical caliber of China and the United States exaggerated the imbalance in trade between the two countries. Fung \& Lau (1998, 2001, 2003a) and Feinstra et al. $(1998,1999,2002)$ estimated the data on China-US trade imbalance, respectively, and concluded that the statistical calibers between China and the US were not consistent and exaggerated the trade imbalance between the two countries. US used FAS and China used FOB, which is $1 \%$ higher than the former. The US export value to China should be adjusted upward by $1 \%$.

\section{The Situation Analysis}

According to the theory of comparative advantage, the two parties in international trade should each export products with comparative advantages to each other, and import products without comparative advantages. For example, in the Sino-US trade, the United States has a comparative advantage in high technology. According to this theory, the US should be the US surplus with China in high-tech products trade, but the actual situation is quite different. The following is an analysis of the current status of Sino-US high-tech trade.

\subsection{The definition of high technology}

Here we define high-tech to analyze the Sino-US trade structure from the perspective of comparative advantage. Therefore, the "high-tech" in this article is the relative technology between the two countries, that is, the United States has a comparative advantage over China. Here we mainly refer to two standards: one is the ten major areas mentioned in the "Made in China 2025" issued by the State Council, including new-generation information technology products, high-end CNC machine tools and robots, aerospace equipment, marine engineering equipment and high technology Ships, advanced rail transportation equipment, energy-saving and new energy vehicles, power equipment, agricultural machinery equipment, new materials, biomedicine and highperformance medical equipment. These ten major areas are proposed in the context of a new generation of information technology revolution, in order to seize the commanding heights of technology with countries around the world and driven by domestic demand. They both reflect the development direction of today's cutting-edge technology and the deficiencies of China's manufacturing industry, which are in line with our definition of high technology. In addition, the U.S. Federal Bureau of Statistics lists information and communication products, optoelectronics, weapons, flexible manufacturing, aerospace, electronics, life sciences and other fields under high technology. Accurate data is available for analysis, so this article will use this as a high-tech definition and analysis standard. 


\subsection{Status and Trend of Sino-US "High-Tech" product trade}

In the circumstances of the overall US-China trade deficit, the United States should have a surplus with China in high-tech areas that the former one holds comparative advantages. However, data from the U.S. Federal Bureau of Statistics shows that in the field of high-tech products, the US trade with China is in an overall deficit, which reached as high as US \$ 123.743 billion in 2014 and even continued to expand as shown in Figure 1. Moreover, the proportion of hi-tech products exported to China accounts for less than $0.1 \%$ of the world's hi-tech products. Against the background of such a large volume of total trade volume between China and the United States, the ratio of US exports to China's hi-tech sector is significantly too small (See Figure 2).

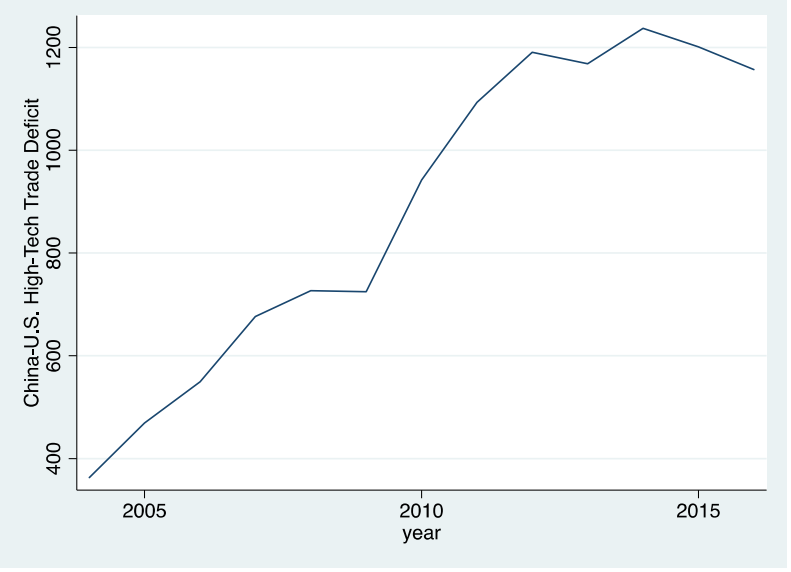

Figure 1. China-U.S. High-Tech Trade Deficit from 2004 to 2016

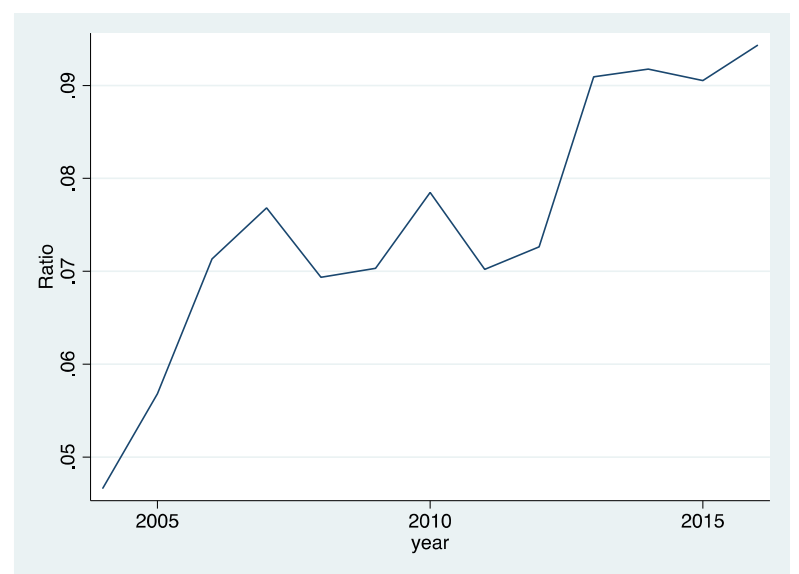

Figure 2. Ratio of U.S. exports of high-tech products to China and U.S. exports to world

Specifically, the United States has a deficit with China in the fields of information and communication, optoelectronics, and weapons, especially information technology products (See Figure 3).

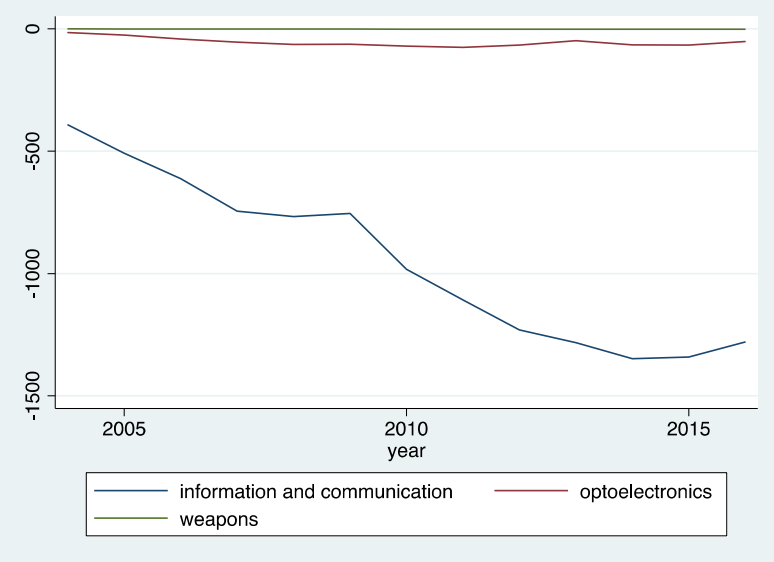

Figure 3. U.S.-China high-tech deficit products from 2004 to 2016

The U.S. surplus of high-tech products to China was only in flexible manufacturing, aerospace, electronics and life sciences. Besides the large surplus in the aerospace field, the gap in other fields was not large, and it has been significantly reduced since 2010 (see Figure 4).

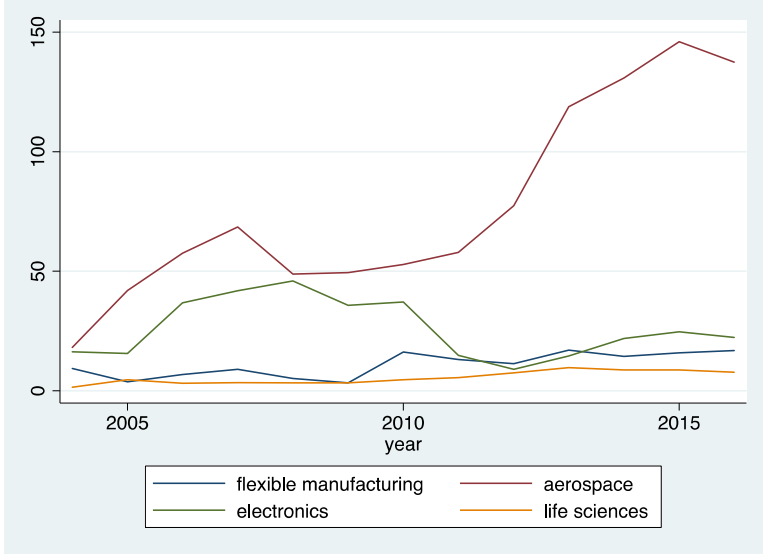

Figure 4. 2004-2016 U.S.-China surplus high-tech products

In summary, according to the theory of comparative advantage, US exports to China's high-tech fields do not conform to the actual conditions of the two countries, and even run counter to known theories. This phenomenon deserves further analysis.

\section{Empirical analysis}

Based on the above analysis, this article attempts to construct a dynamic model for regression estimation by using relevant data, and analyzes the estimated regression results to obtain feasible policy recommendations.

\subsection{The Model and Data}

This article uses a dynamic model to analyze the high-tech trade deficit between China and the United States.

$$
\ln y_{t}=\alpha+\ln y_{t-1}+\beta x_{t}+\varepsilon_{t}
$$

The independent variable is the logarithm of ChinaUS high-tech trade balance, represented by lny, and the data comes from the US Census Bureau. With reference 
to the research of other scholars, the explanatory variables in this article are US export restrictions on high-tech products, the level of innovation in China's high-tech industries, and foreign direct investment. This article uses the ratio of U.S. exports of high-tech products to China to U.S. exports to the world as a proxy for U.S. hi-tech product export restrictions, represented by RATIO. The logarithm of the number of non-resident patents is the proxy variable of innovation level, represented by PAENT, and the data comes from the World Bank Group public database. The proportion of FDI to GDP as the proxy variable of foreign direct investment level in China is represented by FDIGDP. The data sources are the same as above. The paper also uses the lagged independent variable as an explanatory variable in the model to control other unobservable factors. Table 1 gives a statistical description of the data used in this article.

TABLE I. STATISTICAL DESCRIPTION OF VARIABLES

\begin{tabular}{|c|c|c|c|c|c|}
\hline $\begin{array}{l}\text { Varia } \\
\text { bles }\end{array}$ & $\begin{array}{l}\text { Number } \\
\text { of } \\
\text { observat } \\
\text { ions }\end{array}$ & $\begin{array}{l}\text { Mea } \\
\mathrm{n}\end{array}$ & $\begin{array}{l}\text { Stand } \\
\text { ard } \\
\text { deviat } \\
\text { ion }\end{array}$ & $\begin{array}{l}\text { Minim } \\
\text { um } \\
\text { value }\end{array}$ & $\begin{array}{l}\text { Maxim } \\
\text { um } \\
\text { value }\end{array}$ \\
\hline Year & 15 & $\begin{array}{l}201 \\
1\end{array}$ & 4.472 & 2004 & 2018 \\
\hline $\ln y$ & 13 & $\begin{array}{l}6.71 \\
5\end{array}$ & 0.408 & 5.894 & 7.120 \\
\hline $\begin{array}{l}\text { RATI } \\
\text { O }\end{array}$ & 15 & $\begin{array}{l}0.06 \\
0\end{array}$ & 0.014 & 0.036 & 0.079 \\
\hline $\begin{array}{l}\text { PATE } \\
\text { NT }\end{array}$ & 14 & $\begin{array}{l}11.5 \\
47\end{array}$ & 0.226 & 11.076 & 11.820 \\
\hline $\begin{array}{l}\text { FDIG } \\
\text { DP }\end{array}$ & 15 & $\begin{array}{l}3.06 \\
8\end{array}$ & 1.098 & 1.367 & 4.554 \\
\hline
\end{tabular}

Table 2 shows the results of the stationary test. The pvalue is 0.0076 , which indicates that it is a stationary process. PATENT and FDIGDP are stationary after firstorder difference while RATIO after third-order difference.

TABLE II. STATIONARITY TEST

\begin{tabular}{llll}
\hline Variables & Difference & Z Value & P Value \\
\hline lny & 0 & -3.515 & 0.0076 \\
RATIO & 3 & -3.400 & 0.0110 \\
PETENT & 1 & -3.647 & 0.0049 \\
FDIGDP & 1 & -4.703 & 0.0001 \\
\hline
\end{tabular}

\subsection{Regression results and analysis}

$$
\begin{gathered}
\operatorname{lny}=0.77 \ln _{-1}-1.24 R A T I O+0.94 P A T E N T \\
+0.007 F D I G D P
\end{gathered}
$$

From the regression results, we can see that the US government's policy restrictions on the export of hightech products, China's ability to undertake foreign direct investment and China's ability to innovate independently have a effect on the China-US high-tech trade deficit. The regression coefficient of FDIGDP is 0.007 , which indicates that the proportion of FDI to GDP changes by one unit, and lny changes by 0.007 . So the increase in international direct investment has a positive impact on the expansion of the China-US trade deficit. The regression coefficient of patent is 0.94 , which shows that the improvement of China's independent innovation capability will promote the increase of China-US hightech trade deficit. The regression coefficient of lagged lny period is 0.761 , which is significant at the level of $99 \%$, which is consistent with the results of the stationarity test in this paper.

RATIO is the ratio of US exports of high-tech products to China to US exports of high-tech products to the world, reflecting the US government's restrictions on high-tech exports to China. The regression coefficient of RATIO is -1.24 , which indicates that the total share of high-tech products exported by the United States to China increased by one unit, and the Sino-US high-tech trade deficit will decrease by 1.24 . This shows that the US government's relaxation of restrictions on the export of high-tech products to China will have a positive impact on alleviating the imbalance between China and the United States in high-tech trade. Moreover, the absolute value of the US export control variable coefficient is the largest, indicating that the US export control policy is the most significant impact on China-US high-tech product trade imbalance.

In order to further verify the impact of the US government's policy restrictions on the export of hightech products, China's ability to undertake foreign direct investment, and China's increased capacity for independent innovation on the Sino-US high-tech trade deficit, this article conducts a Granger causality test. Table 3 shows the test results. It is obvious that the improvement of China's independent innovation capability, the actual use of foreign capital and the US export controls on China are the reasons for the growing gap between China and the United States in high-tech products, and the reverse causality does not exist.

\begin{tabular}{|c|c|c|}
\hline Null hypothesis & F value & $\mathrm{P}$ value \\
\hline $\begin{array}{l}\text { RATIO is the } \\
\text { Granger cause of } \\
\text { lny }\end{array}$ & 16.77 & 0.003 \\
\hline $\begin{array}{l}\text { lny is the Granger } \\
\text { cause of RATIO }\end{array}$ & 0.28 & 0.761 \\
\hline $\begin{array}{l}\text { PATENT is the } \\
\text { Granger cause of } \\
\text { lny }\end{array}$ & 57.54 & 0.000 \\
\hline $\begin{array}{l}\text { lny is the Granger } \\
\text { cause of PATENT }\end{array}$ & 0.11 & 0.900 \\
\hline $\begin{array}{l}\text { FDIGDP is the } \\
\text { Granger cause of } \\
\text { lny }\end{array}$ & 53.38 & 0.000 \\
\hline $\begin{array}{l}\text { lny is the Granger } \\
\text { cause of FDIGDP }\end{array}$ & 0.65 & 0.543 \\
\hline
\end{tabular}

TABLE III. GRANGER CAUSALITY TEST RESULTS

\section{Conclusions}

The empirical results show that the US export restrictions on China's high-tech trade is an important reason for the significant deficit in the China-US high-tech trade, like 
the United States Export Administration Regulations (hereinafter referred to as the Administrative Regulations) and the United States Export Controlled Commodities List (hereinafter referred to as the List).

The Administrative Regulations expired in 1994, but the current Export Management Regulations continues to be implemented within the scope authorized by the International Emergency Economic Power Law. The Administrative Regulations contain more than 13 control reasons for prohibiting technology exports, and there are more than 11 control reasons for China's high-tech exports. In addition, the List divides the controlled commodities into 10 categories, including computers, telecommunications and information security, navigation and avionics, and spacecraft and other high-tech products. Each of these categories has items that restrict export to China, not only at the product level, but also in productrelated technologies, software, materials, and even test products. On June 15, 2007, the U.S. Department of Commerce officially announced the Amendments and Interpretations of the Export and Re-Export Control Policies of the People's Republic of China; New Verified End-User System; Modification of Import Certificates and Chinese End-User Specification Requirements (Hereinafter referred to as the New Regulations) The "New Regulations" expanded the scope of merchandise for military export licenses to China and required the Chinese Ministry of Commerce to issue end-user instructions, further strengthening restrictions on hightech exports to China. On May 16, 2019, the U.S. Department of Commerce's Industry and Security Administration (BIS) added Huawei Technologies Co., Ltd.

\section{Policy recommendations}

In order to control this factor as the impact of the hightech trade deficit between China and the United States, China can import high-tech products from other high-tech countries, strengthen trade with other countries, expand imports of high-tech products from these countries, and improve its own technology. At the same time, the ability to innovate makes up for the shortage of Chinese imports of high-tech products from the United States.

To fundamentally improve the imbalance between China and the United States in the trade of high-tech products, we must work hard to improve China's technological innovation capabilities and independent research and development levels, enhance the international competitiveness of independent research and development of high-tech products, increase the technological content of export products, and increase international competitiveness Position, thereby promoting the optimization and upgrading of China's export product structure. Firstly, increase R \& D funding for high-tech products, give generous policy subsidies to some companies that focus on technological innovation, and guide and encourage domestic high-tech product manufacturing enterprises to conduct independent technology research and development through policy guidance. Secondly, pay attention to the cultivation of technical talents, the introduction of talents, and attract and retain talents through technological innovation incentives and equity dividend incentive mechanisms.

\section{Reference}

1. Ahmed K, Long W. An Analysis of Core Factors Contributing to U.S - China Trade Imbalance[J]. Mpra Paper, 2012.

2. B.Balassa.Comparative Advantage[J].Trade Policy and Economic Development 1987.Harvester Wheatsheaf.

3. Grossman G M, Helpman E . Trade; Innovation; And Growth[J]. Papers, 1989.

4. Guobing S. U.S. Export Controls and the Issue of the Sino-U.S. Trade Balance[J]. World Economics and Politics, 2006.

5. Heckscher E F. The effect of foreign trade on the distribution of income[M]. 1919.

6. Kennedy. The Political Economy of Standards Coalitions: Explaining China's Involvement in HighTech Standards Wars[J]. Asia Policy, 2006.

7. Li D,The Empirical Research on the Intra-Industry Trade in Sino-US ATP Trade[J]. The Journal of Quantitative \& Technical Economics, 2006.

8. Leamer E E . The Leontief Paradox, Reconsidered[J]. Journal of Political Economy, 1980, 88.

9. Liangping M, Jingchun Z. Sino-U.S.Trade Deficit and Changes in U.S. Trade Protection[J].International Economic Review,2004.

10. Leontief W W . Domestic Production and Foreign Trade: The American Capital Position ReExamined[J]. Proceedings of the American Philosophical Society, 1953.

11. Matthews. Military Modernization in the People's Republic of China: Implications for the United Statesand the Region[M], 1998

12. Meiling K. Analysis of the Causes of Sino-US Trade Imbalance[J]. World Economy Studies, 2006.

13. Ohlin B. Interregional and international trade[M]. Harvard University Press, Cambridge, 1935.

14. Peng C, Pinsan X. The Structural Characteristics and Causes of Sino-US High-tech Product Trade Imbalance[J]. Productivity Research, 2013.

15. Qiang L, Xiaosong W. East-Asian Transferring Effect in Sino-US Trade Imbalance[J]. Economic Review, 2012.

16. Trefler, Daniel. International Factor Price Differences: Leontief was Right![J]. Journal of Political Economy, 1993.

17. Tong S Y . The US-China Trade Imbalance: How Big Is It Really?[J]. China An International Journal, 2005.

18. Uzawa H O . Patterns of Trade and Investment in a Dynamic Model of International Trade[J]. The Review of Economic Studies, 1965. 
19. Wei L. On the "mystery" of China-US high-tech product imbalance[J]. Modern Economic Research, 2009.

20. Yan $\mathrm{W}, \mathrm{He} \mathrm{G}$. The study on China's composition of high-tech products export trade[C]. The 6th International Conference on Information Management, Innovation Management and Industrial Engineering (ICIII), 2013.
21. Ying S, Can L, Zheng-Yu M A. An Analysis of Trade Imbalance of High-tech Products between China and U.S.based on VAR Model[J]. Commercial Research, 2018.

22. Yong-Hua Z. The Export of Value Added in Chinese Manufacturing and China-US Trade Imbalance[J]. Journal of Finance and Economics, 2013. 